\title{
The Use and Development of Podcasting as a Technological Tool in Secondary Education in Greece: A Case Study
}

\author{
Stamatina Nikolou ${ }^{1} \&$ Maria Darra ${ }^{2}$ \\ ${ }^{1}$ English Teacher, Secondary Education, Greece \\ 2 Department of Primary School Education, University of the Aegean, Greece \\ Correspondence: Stamatina Nikolou, English Teacher, Secondary Education, Greece. Tel: 30-697-700-9193. \\ E-mail: tnikolou@gmail.com
}

Received: July 2, $2018 \quad$ Accepted: August 18, $2018 \quad$ Online Published: October 29, 2018

doi:10.5539/ies.v11n11p109 URL: https://doi.org/10.5539/ies.v11n11p109

\begin{abstract}
The main objective of this study is to explore how podcasting can be implemented as a supportive technological tool in teaching English as a Second Language. To this aim, the field experiment research was conducted. The study was carried out in a total of 28 pupils of the first grade of high school at an educational institution on Rhodes, Greece in December 2017. The students were assigned into the experimental group (15 students) and the control group (13 students). A statistically significant difference has arisen regarding the contribution of podcasting to the motivation of the students of the two groups. The students of the experimental group believe that English is a very important school subject which can help them in other subjects. Students found the podcasts interesting and helpful and their content attracted their attention, satisfied their needs and was absolutely relevant to the lesson. All learning styles benefited from the educational podcasts, each one of them in a different way. Finally, the current study proposes specific suggestions for the development of podcasting according to different learning styles.
\end{abstract}

Keywords: learning styles, new technologies, podcasting, second language learning

\section{Introduction}

Foreign language teaching, always pioneering in the field of education, was the first to acknowledge the rapid growth of podcasting, it being one of the most powerful technological tools that have been used in recent years. Several studies about podcasting have explored its potential and have found that educational podcasts can significantly contribute to the development of language skills, in particular speaking and listening (Son, 2018; Ashton-Hay \& Brookes, 2011). Clearly, listening can motivate students who would rather receive information orally than read or take notes (Hinkelman, 2018). As well as this, podcasting can make the content of the lesson more attractive to students, giving them the opportunity to incorporate speaking in the learning process. Teachers, in turn, can create a more interesting and collaborative learning environment (Abdous, Facer, \&Yen, 2012; Abt \& Berry, 2007).

The portability and the convenience of listening to their resources are yet another technological advantage that podcasting offers in language learning. Students can learn the language outside the traditional school classroom at their own pace at the time and place of their choice (Vavouraki, 2004). The educational benefits of podcasting give the opportunity to learners to use the language in authentic context, thus helping them develop speaking skills and correct pronunciation (Bin, Xinxin, \&Hui, 2017).

Podcasting becomes the tool which can help language teachers encourage their students to apply the language skills they have acquired in an active form of communication and not just use them as a means for collecting information (Wrigglesworth \& Harvor, 2017; Yoshida, 2013; Ashton-Hay \& Brookes, 2011). For instance, the process of creating a podcast can enhance further skills apart from speaking, such as listening, interviewing, script writing and communication (Bin et al., 2017; Scutter et al., 2010).

Studies that have been conducted globally indicate that the implementation of podcasting can promote positive learning results. Such examples are the studies of Ashraf, Noroozi, and Salami (2011), Istanto (2011), Kan (2011) and Hawke (2010), all of whom have recorded positive perceptions of the participants and concluded that podcasting can improve the listening skills of ESL (English as a Second Language) students. Similarly, Vidal (2010), Putman and Kingsley (2012) and Borgia (2010) conducted studies assigned to university students, which 
demonstrated that podcasts can significantly reinforce academic vocabulary acquisition. More studies in English and American universities, such as the ones of Ashton-Hay and Brookes (2011) and Edirisingha (2007), illustrated the substantial contribution of podcasting to the elaborate preparation of students for workshops and seminars, its full support to students regarding assignment evaluation and its valuable advice for the creation of portfolios and assignment presentations.

In Greece, podcasting as a technological tool has barely been used in education. Kokkini (2010) investigated whether the learning process supported by podcasts can enhance students' skills in geometry, whereas Kravari (2011) made a research on how podcasts can be implemented in teaching the French language in primary education. The results of both studies showed that podcasts' educational value is held upon acquiring specific skills on the students' account. Further studies regarding the incorporation of New Technologies and Computer Assisted Language Learning (CALL) in Greek education are the ones of Tsimogiannis and Komis (2010), Shoretsanitou and Vekyri (2010) and Panagopoulos (2010). The researchers found that the new technologies can be invaluable educational tools. However, Greek teachers are not always positive in introducing them excessively in their classes and, therefore, not utterly convinced of the efficacy of the teaching outcomes when instructional technologies are used.

\section{Importance of the Research}

There has been a relatively limited number of studies investigating the pedagogical value of podcasting as an instructional aid both in Greece and internationally, as most international studies have investigated the use of podcasting in tertiary education, As well as this, there is total absence of studies regarding the use of podcasting in the English language classes in the secondary education. The present study attempts to fill both gaps, that is, the contribution of podcasting to teaching English as a Second Language and the subsequent investigation of its pedagogical value. The results will cast light on the application of podcasting in high schools, as the current study will endeavor to illustrate how the integration of the given technology can deliver positive results towards the achievement of specific learning objectives. As well as this, the study will show how the motivation of the students triggered by podcasting can effectively lead to the achievement of learning objectives and the development of language skills through the design, the implementation and the evaluation of the educational intervention supported by the innovative technology.

\section{Literature Review}

A thorough literature review identified 15 international studies and 5 studies in Greece, whose scope was podcasting. The following paragraphs summarize the results of these studies.

Podcasts can facilitate the learning process and challenge traditional teaching (Chakowa, 2018; Lee \& Chan, 2007). The results of Hawke's study (2010) showed that learners' listening skills after using podcasts were significantly higher than before and that podcasts as support tools help students focus their attention on the content of the lesson. Ashraf, Noroozi, and Salami (2011) concluded that podcasts can contribute to developing and improving ESL students listening skills. Similarly, Istanto (2011) acknowledges that podcasting is an innovative technology with enormous potential for the improvement of listening skills. Students can download authentic podcasts from the Internet and get further practice in listening (Artyushina, Sheypak, Khovrin, \& Spektor, 2011). Many resources with authentic podcasts can be found on the web which can boost learners' listening skills (Bin et al., 2017; Sabet \& Mahsefat, 2012). Kan (2011) analyzed and assessed a language learning website for the development of listening skills with the use of podcasts and suggested that the site designers should clarify their objectives, organize the content and enrich their exercises more frequently in order to meet the needs of students as far as listening skills development is concerned.

Podcasts can also be used effectively for the improvement of pronunciation with exercises of phonetics. The ESL learners can get as much practice as they need by repeating the recordings. Chakowa (2018) and Ducate and Lomicka (2009), who have conducted studies in order to evaluate the perceptions of learners to pronunciation, found that learners' pronunciation did not improve significantly during the classes due to lack of time, yet podcast projects with phonetics carried out by learners were quite effective.

Podcast use produced positive results in vocabulary development and acquisition, as teaching new vocabulary can be easily incorporated in a podcast. Many researchers have observed that listening affects vocabulary acquisition and retention much more than reading, as vocabulary information is processed more deeply through listening (Putman \& Kingsley, 2009; Borgia, 2010; Vidal, 2010). Hinkelman (2018) and Borgia (2010), who have conducted such studies, support that podcasting can have positive impact on the students' vocabulary learning. Vidal (2010) explored whether reading the course book material gives more time for processing new words in comparison to listening to recorded speech and concluded that educational podcasts can substantially contribute to 
storing new vocabulary in long-term memory.

Educational podcasts have been studied in relation to learning strategies, as second language learning has to be designed in a particular instructional framework (Schmidt \& Strasser, 2018). Second language acquisition is not achieved only in class. It can be accomplished at any place and at any time, which is podcasts' definite advantage. Yim, Saito - Stehberger \& Warschauer (2017) and Ashton-Hay \& Brookes (2011) conducted studies whose main objective was to explore the learning strategies from the use of podcasts created by learners. Both concluded that mobile learning can enormously contribute to second language acquisition.

In Greece, several studies have been conducted examining the effectiveness of mobile learning and the inclusion of Information Technology and the implementation of technological tools in education. Podcasting as an instructional tool has been an integrated part of these studies and its educational value has been proved to have radically changed educational disciplines. More specifically, Tsimogiannis and Komis (2010) consider that on account of podcasting the school day is extended constructively and this helps learners reconsider their views on quizzes, tests and evaluation in general. Similarly, Schoretsanitou and Vekyri (2010) agree that teachers use podcasting as a means to effectively interact with their pupils outside the traditional school classroom. In their studies, there are examples of teachers who turn their lectures from PowerPoint presentations to podcasts. Other teachers create podcasts where they provide detailed explanations to frequently asked questions or, even more, they make use of podcasts as a tool for further vocabulary practice (Panagopulos, 2010; Tsimogiannis \& Komis, 2010; Schoretsanitou \&Vekyri, 2010).

Kokkini (2010) and Kravari (2011), who have conducted studies about the effective implementation of educational podcasts in or out of the school class, acknowledge the importance of podcasts created by students as a productive means of interaction with teachers and other students. Both researchers have used podcasting technology in order to provide their students with supplementary online material but have concluded that the results of their teaching interventions did not convince them of the effectiveness of podcasting in the improvement of learning skills.

\section{Research Questions}

Based on the above, the main purpose of this study is to investigate the contribution of podcasting to the development of learners' language skills in the ESL class of the first grade of high school. In particular, the present study aims at adding to the literature by exploring the effectiveness of podcasting in achieving specific learning objectives and in motivating learners towards studying English. The case study is conducted in Greece but its results can be applicable to ESL classes around the world. Based on the gap in the literature, the study addresses the following research questions:

1) Are learners motivated by the use of podcasting?

2) Is there any significant difference between the control and the experimental group in achieving the learning objectives and in developing language skills by the use of podcasting?

\section{Employing Podcasts in English Language Learning: Theoretical Framework}

Greek and international studies argue that educational podcasts significantly enhance the learning process (Dendrinou, 2013). Developing listening skills is one of the obvious learning objectives of using podcasting in second language classes. It is also suggested that podcasts contribute to vocabulary acquisition, development of grammar and improvement of pronunciation (Chakowa, 2018; Rezapour, Gorjian, \& Pazhakh, 2012; Ng'ambi, 2008). What makes employing podcasts in language learning particularly important is the extension of the teaching day, the engagement of students to the content of the course and, consequently, the transformation of the traditional class (Lee, Tan \& Goh, 2004). In the case of podcasts developed by teachers, the teacher's human voice significantly affects the way the students' process information, in contrast to digital voice (Rosell-Aguilar, 2017).

Another advantage of portable wireless technologies, such as podcasts, is that students can choose the place and the time they will use them. For example, absent pupils can recover part of the lesson they missed, by listening to the podcast the teacher created in order to meet this need. Furthermore, podcasts are more effective revision tools than textbooks, and they are also more efficient than traditional note taking thanks to the flexibility of access (Rosell-Aguilar, 2017; Fisher \& Kim, 2013; Kim, 2009, 2011). Teachers can assist students in creating podcasts, thus featuring an online learning environment which fosters high motivation towards the course (Yim et al., 2017; Bolliger, Supanakorn, \& Boggs, 2012).

Educational podcasts taxonomy (see Figure 1) is the following: a. Podcasts created by the teacher for the needs of his class. b. Podcasts published on the internet by educational institutions, ready to use by teachers and students. c. Podcasts created by students as part of an assignment. d. Authentic podcasts found on radio stations, televisions, and newspapers websites (Rossell-Aguilar, 2007). 


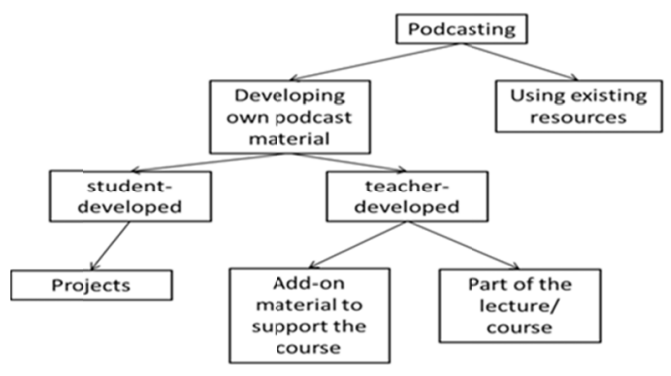

Figure 1. Taxonomy of current practices of podcast (adapted from Rossell-Aguilar, 2007)

Podcasting has high pedagogical value and provides unique enhancement to the learning process as the learner constructs knowledge through active exploration, observation, processing, and interpretation (Rosell-Arguilar, 2007) while interacting with others. It has also been argued that students who use authentic podcasts on a daily basis rarely use dictionaries due to their exposure to authentic speech production (Popova \& Edirisingha, 2010) as they have genuine opportunities to practice both their listening and speaking skills. It is clear that all learning types can benefit from educational podcasts through their research, production and listening process (Bin et al., 2017; Sweeny, 2005). Eventually, pupils' communication strategies are enhanced by the usefulness and practicality of audio files (Jonassen, Carr, \& Yueh, 1998; Evans, 2008). By creating their own podcasts, students can demonstrate what they have learnt, review and reflect upon the content of the lesson. They can also connect with schools and students beyond their geographical boundaries (Yim et al. 2017; Kennedy, 2014; Abdous et al., 2012; Istanto, 2011).

\section{Method}

\subsection{The Participants}

The selected method to answer the research questions is the field experiment. It was employed with the first grade of high school in the private school "Rodion Pedia" on Rhodes. The study recruited 28 12-year-old learners, 15 of whom were assigned to the experimental group and the other 13 were assigned to the control group. The students selected for the research had demonstrated moderate school performance. In both groups all students were A2 proficiency level, based on the Common European Framework of Reference for Languages. This means that they had been studying English for 5-6 years. Both groups consisted of a balanced number of boys and girls; therefore, equivalence between the two groups was at large achieved.

\subsection{Research Instruments}

The research instruments used were four questionnaires and a final assessment test. The first questionnaire consisted of two parts and included 19 items. The first part portrays the students' profile, that is gender, age, grade and learning style, and the second one explores the students' familiarity with technologies, technological devices and the Internet. Each item was measured on a 7-point Likert-type scale.

The first research question was explored supported by two separate questionnaires, the MSLQ (Motivated Strategies for Learning Questionnaire) (Pintrich, 1991) and the IMMS (Instructional Materials Motivation Survey). The MSLQ was composed of eight items. Four of them were designed to sustain the intrinsic motivation of students whereas the other 4 explored their extrinsic motives. What was actually investigated was how students use existing knowledge to understand new ideas and how they organize learning material (Duncan \& McKeachie, 2005). This questionnaire was answered by the students of both groups (experimental group and control group) after the teaching intervention and before the final assessment. The IMMS is a widely used instrument measuring the individual motivational state levels. The instrument is developed under the ARCS model of Keller (1987) to measure learner's motivation levels. According to this model, four factors are identified as important: attention, relevance, confidence and satisfaction. The questions were adapted for the needs of the present study, which was about the use of podcasting as a supportive educational tool for the pupils of the experimental group to use and practice outside of the school environment. The questionnaire was composed of 12 items and was given to the students of the experimental group after the end of the teaching intervention and before the final written assessment.

In order to collect data and investigate the second research question, a written assessment was assigned both to the experimental group and the control group at the final stage of the educational scenario. Cohen, Manion, and Morrisson (2008) suggest that written tests employed as assessment methods are effective in collecting data. 


\subsection{Pedagogical Intervention}

For the design of the educational scenario, the $5 \mathrm{E}$ instructional model was used, which was based on the principles of constructivism. Each of the 5 E's describes a phase of learning, and each phase begins with the letter "E": Engage, Explore, Explain, Elaborate, and Evaluate (Bybbe, 2006). Both the control and the experimental group were assigned the same educational scenario, but only the experimental group used podcasting as a supportive tool for developing listening and language skills. Podcasting is a scaffolding tool for cultivating, developing and enhancing language skills both in written and in spoken language. The educational intervention was designed in the light of the teaching objectives and on the basis of the research questions and lasted 5 weeks. The specific teaching objectives for the development of language skills were defined according to the Cross-Curricular Program of Foreign Language Studies as designed by the Institute of Educational Policy of Greece (DEPPS-FL).

\section{Results}

The statistical analysis of the data was performed using the statistical package SPSS 23.0.

\subsection{Learners' Profile}

To accomplish the purposes of the present study 28 students of the first grade of high school were assigned to two groups (experimental group: 15 participants, control group: 13 participants). As it can be seen in Table 1, the two groups have a balanced number of boys and girls, whereas the experimental group consists of two more students than the control group.

Table 1. Group and gender relative frequency

\begin{tabular}{cccc}
\hline \multicolumn{2}{c}{ Group } & \multicolumn{2}{c}{ Gender } \\
\hline Control Group & Experimental Group & Female & Male \\
13 & 15 & 14 & 14 \\
\hline
\end{tabular}

The pie charts in Figure 2 show that the majority of students belong to the visual learning type; the auditory types come next, while the kinesthetic are clearly fewer. What is very interesting to see is how the three learning types responded to the new pedagogical approach.

1)

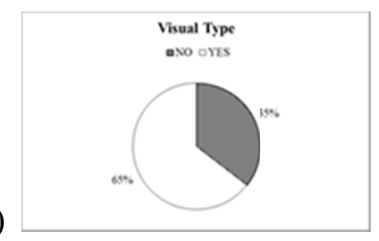

2)

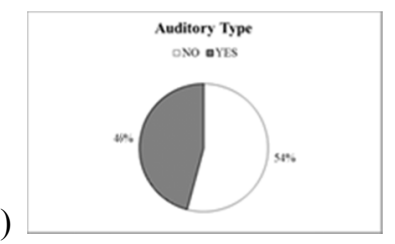

3)

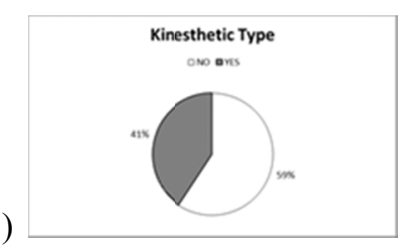

Figure 2. 1) Visual Type-Understanding images more than text; 2) Auditory Type-Learning via oral explanation; 3) Kinesthetic-Learning via handcraft

Table 2 summarizes the results of the participants' profile and demonstrates an enormous familiarization of the students with computers and related technologies. The vast majority responded positively to all the questions about the internet, web site management and their engagement to electronic devices. 
Table 2. Summary of participants' profile

\begin{tabular}{|c|c|c|c|c|c|c|c|c|}
\hline \multicolumn{9}{|l|}{ Test Statistics $^{\mathrm{a}}$} \\
\hline & & $\begin{array}{l}\text { Strongly } \\
\text { Disagree }\end{array}$ & Disagree & $\begin{array}{c}\text { Moderately } \\
\text { Disagree }\end{array}$ & Undecided & $\begin{array}{c}\text { Moderately } \\
\text { Agree }\end{array}$ & Agree & $\begin{array}{c}\text { Strongly } \\
\text { Agree }\end{array}$ \\
\hline When I do my homework, & Frequency & 4 & 2 & 1 & 6 & 6 & 3 & 6 \\
\hline $\begin{array}{l}\text { underlying helps me put my } \\
\text { thoughts in order }\end{array}$ & Percentage & 14.3 & 7.1 & 3.6 & 21.4 & 21.4 & 10.7 & 21.4 \\
\hline I learn better when someone & Frequency & 1 & 0 & 0 & 3 & 4 & 7 & 13 \\
\hline $\begin{array}{l}\text { explains what I can't } \\
\text { understand }\end{array}$ & Percentage & 3.6 & 0.0 & 0.0 & 10.7 & 14.3 & 25.0 & 46.4 \\
\hline Spending time with & Frequency & 2 & 1 & 4 & 2 & 3 & 2 & 14 \\
\hline $\begin{array}{c}\text { computers appeals a lot to } \\
\text { me }\end{array}$ & Percentage & 7.1 & 3.6 & 14.3 & 7.1 & 10.7 & 7.1 & 50.0 \\
\hline When I do my homework, it & Frequency & 8 & 5 & 3 & 8 & 1 & 2 & 1 \\
\hline $\begin{array}{l}\text { helps me drawing charts or } \\
\text { tables }\end{array}$ & Percentage & 28.6 & 17.9 & 10.7 & 28.6 & 3.6 & 7.1 & 3.6 \\
\hline I like spending my free time & Frequency & 1 & 1 & 2 & 1 & 2 & 8 & 13 \\
\hline browsing the internet & Percentage & 3.6 & 3.6 & 7.1 & 3.6 & 7.1 & 28.6 & 46.4 \\
\hline I'd rather play on my & Frequency & 10 & 4 & 6 & 2 & 4 & 1 & 1 \\
\hline $\begin{array}{c}\text { computer rather than any } \\
\text { other game }\end{array}$ & Percentage & 35.7 & 14.3 & 21.4 & 7.1 & 14.3 & 3.6 & 3.6 \\
\hline It's easy for me to turn on & Frequency & 0 & 0 & 0 & 1 & 1 & 1 & 25 \\
\hline and off a computer & Percentage & 0.0 & 0.0 & 0.0 & 3.6 & 3.6 & 3.6 & 89.3 \\
\hline Helping my friends with & Frequency & 0 & 1 & 0 & 3 & 4 & 7 & 13 \\
\hline computers is easy for me & Percentage & 0.0 & 3.6 & 0.0 & 10.7 & 14.3 & 25.0 & 46.4 \\
\hline Surfing the internet is easy & Frequency & 0 & 0 & 1 & 1 & 0 & 4 & 22 \\
\hline for me & Percentage & 0.0 & 0.0 & 3.6 & 3.6 & 0.0 & 14.3 & 78.6 \\
\hline I often use MP3, tablets, or & Frequency & 3 & 2 & 3 & 2 & 4 & 4 & 10 \\
\hline $\begin{array}{l}\text { other electronic devices on } \\
\text { my free time }\end{array}$ & Percentage & 10.7 & 7.1 & 10.7 & 7.1 & 14.3 & 14.3 & 35.7 \\
\hline
\end{tabular}

\section{$7.21^{\text {st }}$ Research Question: Motivation}

The first research question investigates how the use of podcasting has affected the motivation of the students. Both the control group and the experimental group responded to the Motivated Strategies for Learning Questionnaire (MSLQ). The experimental group also responded to the Instrumental Materials Motivation Survey (IMMS). The statistical analysis of the data was conducted with the use of the non-parametric Mann-Whitney U test between two independent samples with a view to acceptance or rejection of null hypothesis $\left(H_{0}\right)$ versus the alternative $\left(H_{1}\right)$ for each item of the questionnaire.

As shown in Table 3, it seems that the null hypothesis is rejected in all cases, except for the question "I'm thinking that I will be able to use what I learn in English to other school subjects ", where p-value $=0.001$ was lower than $\alpha$. This means that there is statistically significant difference between the motivation of the experimental group (EG) and the control group (CG). Namely, the students of the experimental group believe that the knowledge they acquire from English can be useful to other school subjects and that the knowledge of the English language can support other subjects. This is a very important result which is worth further analysis. 
Table 3. Significance levels of Mann-Whitney $U$ test about the 8 mobilization equations of the two group students

\begin{tabular}{|c|c|c|c|c|c|c|c|c|}
\hline & $\begin{array}{c}\text { I prefer } \\
\text { classwork } \\
\text { that is } \\
\text { challenging } \\
\text { so I can learn } \\
\text { new things }\end{array}$ & $\begin{array}{l}\text { I think I } \\
\text { will be } \\
\text { able to } \\
\text { use what I } \\
\text { learn in } \\
\text { the } \\
\text { English } \\
\text { class in } \\
\text { other } \\
\text { classes }\end{array}$ & $\begin{array}{l}\text { I often } \\
\text { choose } \\
\text { paper topics } \\
\text { I will learn } \\
\text { something } \\
\text { from even if } \\
\text { they require } \\
\text { more work }\end{array}$ & $\begin{array}{l}\text { Understanding } \\
\text { this subject } \\
\text { thouroughly is } \\
\text { important to me }\end{array}$ & $\begin{array}{l}\text { It is } \\
\text { important } \\
\text { to me to } \\
\text { get good } \\
\text { grades }\end{array}$ & $\begin{array}{l}\text { If I have a } \\
\text { chance I } \\
\text { choose an } \\
\text { exercise I } \\
\text { will learn } \\
\text { something } \\
\text { from even if } \\
\text { I don't get a } \\
\text { good grade }\end{array}$ & $\begin{array}{l}\text { When I } \\
\text { take a } \\
\text { test I } \\
\text { think } \\
\text { about } \\
\text { how } \\
\text { poorly I } \\
\text { am doing }\end{array}$ & $\begin{array}{l}\text { I work hard } \\
\text { to do well } \\
\text { because it is } \\
\text { important } \\
\text { for me to } \\
\text { show my } \\
\text { abilities to } \\
\text { my parents. } \\
\text { my teachers } \\
\text { and my } \\
\text { friends }\end{array}$ \\
\hline $\begin{array}{c}\text { Mann-Whitney } \\
\text { U }\end{array}$ & 67.500 & 30.000 & 66.000 & 76.000 & 73.000 & 72.000 & 93.000 & 85.000 \\
\hline Wilcoxon W & 158.500 & 121.000 & 157.000 & 167.000 & 193.000 & 163.000 & 213.000 & 205.000 \\
\hline $\mathrm{Z}$ & -1.456 & -3.153 & -1.509 & -1.037 & -1.155 & -1.199 & -.213 & -.598 \\
\hline $\begin{array}{l}\text { Asymp. Sig. } \\
\text { (2-tailed) }\end{array}$ & .145 & .002 & .131 & .300 & .248 & .231 & .832 & .550 \\
\hline $\begin{array}{l}\text { Exact Sig. } \\
\text { [2*(1-tailed } \\
\text { Sig. })]\end{array}$ & $.170^{\mathrm{b}}$ & $.001^{\mathrm{b}}$ & $.156^{\mathrm{b}}$ & $.339^{\mathrm{b}}$ & $.274^{\mathrm{b}}$ & $.254^{\mathrm{b}}$ & $.856^{\mathrm{b}}$ & $.586^{\mathrm{b}}$ \\
\hline
\end{tabular}

a. Grouping Variable; b. Not corrected for ties - Test Statistics ${ }^{\mathrm{a}}$

The second part of the questionnaire attempted the measurement of the four factors of Keller's (1987), which measures the motivation levels of confidence, satisfaction, attention and relevance. As shown from the analysis of the data, a relatively high motivation was generated by the use of the podcasts, which can potentially increase.

As it is clear from the pies in Figures 3 and 4, the level of "confidence" seems to be 44\%, which does not form an important motivation factor regarding the use of podcast. The factor "satisfaction", though, with a percentage of $69 \%$, demonstrates a serious motivation level. The factor "attention" rises up to $56 \%$. This means that the majority of the students consider the podcast experience as a new learning environment that deserves their attention. This factor becomes more important if combined with the factor "satisfaction". It is evident that the podcast is a new technology which is appealing to students and at the same time students are satisfied by its use. The factor "relevance" reached $51 \%$, whereas its corresponding lower level is limited to $27 \%$. It is, therefore, inferred that half the students of the experimental group believe that the podcast is directly related to the content of the lesson.
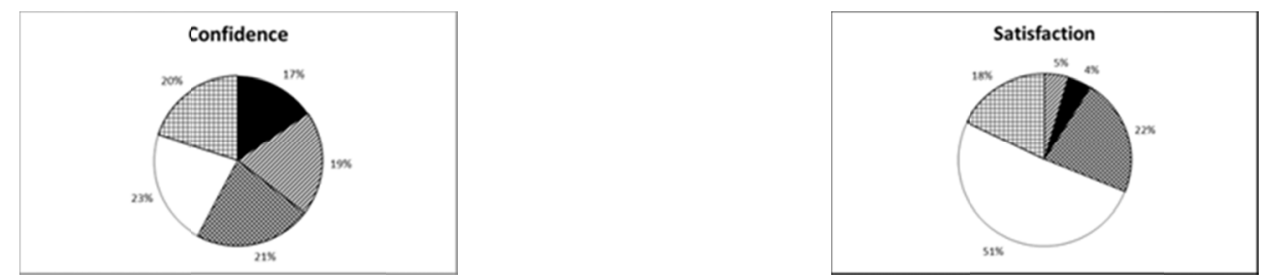

Figure 3. Percentage motivation of the experimental group regarding the factors "Confidence"-"Satisfaction" of Keller's model 

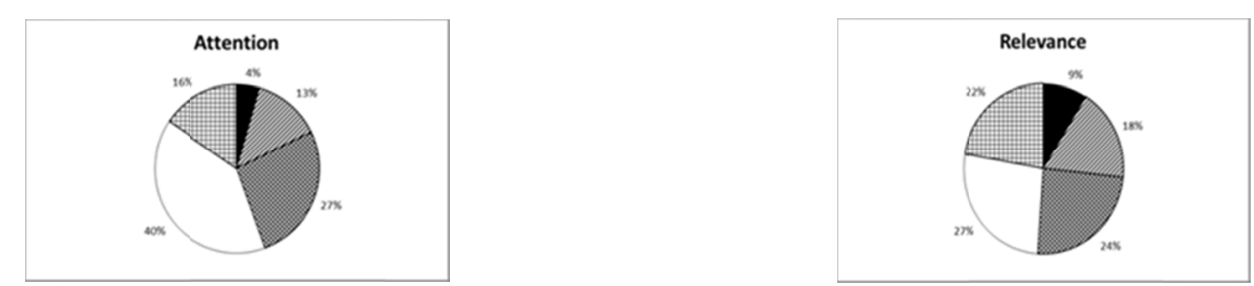

Figure 4. Percentage motivation of the experimental group regarding the factors "Attention"-"Relevance" of

Keller's model

\section{$7.32^{\text {nd }}$ Research Question: Achievement of the Learning Objectives}

The final assessment test was the instrument for the fourth research question, with the aim to investigate whether particular learning objectives have been achieved. In Tables 5 and 6 can be found the frequency and relative frequency distributions of the scores for each group.

Table 5. Frequency and relative frequency distributions of the final assessment score for the EG students.

\begin{tabular}{ccc}
\hline Grading System: Excellent (10) & Relative Frequency & Frequency $\%$ \\
\hline $9-10$ & 7 & $46.8 \%$ \\
$7-8$ & 4 & $26.6 \%$ \\
$4-6$ & 4 & $26.6 \%$ \\
Total & 15 & $100 \%$ \\
\hline
\end{tabular}

Table 6. Frequency and relative frequency distributions of the final assessment score for the CG students.

\begin{tabular}{ccc}
\hline Grading System: Excellent (10) & Relative Frequency & Frequency $\%$ \\
\hline $9-10$ & 3 & $23.1 \%$ \\
$7-8$ & 3 & $23.1 \%$ \\
$4-6$ & 7 & $53.8 \%$ \\
Total & 13 & $100 \%$ \\
\hline
\end{tabular}

The EG group seems to gain an advantage over the CG. For the analysis of the final assessment test the average score of each team (EG and $\mathrm{CG}$ ) was compared using the independent samples t-test. This hypothesis test measured the same variable between two independent samples (EG and CG). The result of the data analysis showed that $p$-value $=0.501>0.05$, therefore the null hypothesis was not rejected. Hence, the scores of the two groups do not have statistically significant difference.

These results required further analysis with an innovative process. To this aim, the score of each student was adjusted based on their learning type (visual, auditory, and kinesthetic). The statistical hypothesis test remained the same with the difference that it was now adjusted to the students learning styles. 
Table 7. Adjusted score per learning type

\begin{tabular}{|c|c|c|c|c|c|c|c|c|c|c|}
\hline & & \multicolumn{3}{|c|}{$\begin{array}{c}\text { Levene's Test } \\
\text { for Equality of } \\
\text { Variances } \\
\end{array}$} & \multicolumn{6}{|c|}{ t-test for Equality of Means } \\
\hline & & \multirow[t]{2}{*}{$\mathrm{F}$} & \multirow[t]{2}{*}{ Sig. } & \multirow[t]{2}{*}{$\mathrm{t}$} & \multirow[t]{2}{*}{ df } & \multirow[t]{2}{*}{$\begin{array}{l}\text { Sig. } \\
\text { (2-tail } \\
\text { ed) }\end{array}$} & \multirow[t]{2}{*}{$\begin{array}{c}\text { Mean } \\
\text { Difference }\end{array}$} & \multirow[t]{2}{*}{$\begin{array}{l}\text { Std. Error } \\
\text { Difference }\end{array}$} & \multicolumn{2}{|c|}{$\begin{array}{c}95 \% \text { Confidence } \\
\text { Interval of the } \\
\text { Difference }\end{array}$} \\
\hline & & & & & & & & & Lower & Upper \\
\hline SCORE_VIS & $\begin{array}{l}\text { Equal variances } \\
\text { assumed }\end{array}$ & .005 & .944 & $\begin{array}{c}-3.01 \\
2\end{array}$ & 26 & .006 & -17.65641 & 5.86185 & $\begin{array}{c}-29.7056 \\
2\end{array}$ & $\begin{array}{c}-5.6072 \\
0\end{array}$ \\
\hline UAL & $\begin{array}{c}\text { Equal variances not } \\
\text { assumed }\end{array}$ & & & $\begin{array}{c}-3.00 \\
4\end{array}$ & 25.144 & .006 & -17.65641 & 5.87748 & $\begin{array}{c}-29.7578 \\
0\end{array}$ & $\begin{array}{c}-5.5550 \\
2\end{array}$ \\
\hline SCORE_AU & $\begin{array}{c}\text { Equal variances } \\
\text { assumed }\end{array}$ & 1.058 & .313 & $\begin{array}{c}-3.15 \\
6\end{array}$ & 26 & .004 & -16.62564 & 5.26834 & $\begin{array}{c}-27.4548 \\
6\end{array}$ & $\begin{array}{c}-5.7964 \\
2\end{array}$ \\
\hline DITORY & $\begin{array}{c}\text { Equal variances not } \\
\text { assumed }\end{array}$ & & & $\begin{array}{c}-3.23 \\
3\end{array}$ & 25.153 & .003 & -16.62564 & 5.14282 & $\begin{array}{c}-27.2142 \\
1\end{array}$ & $\begin{array}{c}-6.0370 \\
7\end{array}$ \\
\hline SCORE_KIN & $\begin{array}{c}\text { Equal variances } \\
\text { assumed }\end{array}$ & 4.760 & .038 & -.720 & 26 & .478 & -4.58462 & 6.36920 & $\begin{array}{c}-17.6767 \\
0\end{array}$ & 8.50747 \\
\hline ESTHETIC & $\begin{array}{c}\text { Equal variances not } \\
\text { assumed }\end{array}$ & & & -.748 & 22.703 & .462 & -4.58462 & 6.13224 & $\begin{array}{c}-17.2793 \\
1\end{array}$ & 8.11008 \\
\hline
\end{tabular}

It is clear from Table 7 above that the average performance of students of the two groups is statistically significant when the grade is adjusted according to whether the student belongs to the visual and the auditory type whereas there is no statistically significant difference between the two groups in their average performance when the score is adjusted to the kinesthetic style. Visual and auditory learning types achieved the best scores in the written assessment, while the kinesthetic learning types failed to perform so well.

\section{Discussion}

\subsection{1st Research Question: Students Motivation}

The results of this study on student motivation are in agreement with those of Hinkelman (2018) and Shahramiri and Gorjian (2013), who support that students' motivation and attitudes are probably the key elements to success or failure of any complex task. Keller's motivation research instrument of this study showed statistically significant results for satisfaction, attention and relevance, which is in line with Reed (2010), who urges that learning a foreign language with the right motivation the student's success is certain. The results regarding the factors of satisfaction, attention and relevance are also in agreement with $\mathrm{Ng}$ 'ambi (2008), who argues that podcasts create an interactive environment between the content and its listeners. It is certain that the English language is of particular interest to the Greek students to learn and to acquire. In fact, there is no Greek student who has not taken English courses at some stage of his or her school career and most students aim very high. Their target is to gain a high level of language acquisition that will be accredited with official certification. This fact has obviously generated the motivation of students so as to consider the English courses as very important, and also realise that the knowledge they get may enable them to have a good performance in other school subjects too.

\subsection{2nd Research Question: Achievement of Learning Objectives}

According to the results of the current study, the students of the experimental group did not have statistically significant better results than the ones of the control group. However, this did not prevent them from engaging to the new technological tool, being excited with the unprecedented process and sharing a new experience which would seem particularly interesting and helpful to them. These results have been well anticipated, as they are in line with other similar studies conducted both in Greece and internationally and concern the incorporation of New Technologies into the educational process (Wrigglesworth, 2017; Karathanassis, 2012). Students are always attracted by this process, at least at the beginning, and that is why their language skills improve (Vavouraki, 2001; 2004).As well as this, literature argues that listening skills are considered synonymous with language understanding (Lawlor \& Donnelly, 2010; Cebeci \& Tekdal, 2010). The results of the present study are in line with this assumption. Finally, the results of this study are in agreement with many previous studies which support that lessons with podcasts improve students' learning experiences. Students benefit particularly from acquiring listening skills and further language skills (Chakowa, 2018; Kennedy, 2014; Istanto, 2011). 
What were of particular concern of the researchers were the learning styles of the students who participated in the teaching intervention. The findings of this study fully agree with Sweeny (2005), who argues that using podcasts to distribute the content of the lesson can affect learners of different learning styles. Obviously, kinesthetic types, although they are the minority, are attracted by the portability of podcasts, while auditory learners are best activated with the verbal-linguistic approach of narrative podcasts.

Students found podcasts interesting and helpful, and in combination with the human voice of their teacher, the content of the audio files became even more appealing. This result is in agreement with Chakowa (2018) and Veronikas and Maushak (2005), who stated that there is evidence that, the recorded audio narrative can be effective and beneficial as an educational tool. It also agrees with Bin et al. (2017) and Lum (2006), who argue that listening to authentic recordings is a pleasant and effective activity, through which students are actively involved in understanding the language. Students of the English language have very few opportunities to use it outside of the classroom, so it is very important that teachers provide them with the authentic opportunities to practice their oral skills (Yoshida, 2013). In this case though, teacher created podcasts were used to help students improve their self-study skills, as it is supported by the literature (Son, 2018; Stanley, 2006).

\section{Limitations of the Study}

Despite the positive results from implementing podcasting to motivate students, there are some limitations that should be mentioned. This study was conducted only in English classes for students of the first grade of a private secondary school in Greece. The sample of 28 students was relatively small. A larger sample would increase the credibility of the study. There were also time constraints on the implementation of the research program, which did not allow its longer duration. Eventually, the fact that learners were not at all familiar with podcasting was another restriction, as it is not certain whether students used this technology correctly while practicing outside of the school.

\section{Conclusion and Pedagogical Implications}

\subsection{Significance of the Results}

Regarding podcasting's contribution to students' motivation, there is a significant difference between students' motivation of the two research groups. A statistically significant difference has also emerged as students of the experimental group consider that English is a very important subject that can help them in other subjects. In addition, regarding the motivation levels of the students of the experimental group based on the model of Keller, for the factors of 'satisfaction', 'attention' and 'relevance', it turns out that the students of the experimental group stated that the content of the recorded files attracted their attention, it was absolutely relevant to the lesson and satisfied their needs. Eventually, it appears that 'confidence' is not important to the use of podcasts.

The second research question investigated the achievement of the learning objectives by implementing podcasting as a supportive tool. Furthermore, its effectiveness has been associated with each learning style. This is an innovation of the present study which aims at contributing to the literature. According to the research results, it appears that there are statistically significant differences between the visual types, who are the majority in the experimental group, and the auditory types that follow in number. Podcasts proved to have been significantly beneficial for all learning styles. Visual and auditory types performed better than the kinesthetic types in the final assessment, but the kinesthetic seemed more interested in the podcasts' content than the others.

Nonetheless, further implications should be taken into consideration based on the results of this study and its limitations. First and foremost, the study has seriously contributed to changing the students' attitudes and beliefs, mostly towards learning the English language and the way English is being taught. Additionally, both the students' interest in the course and their self-confidence in their skills have been significantly stimulated by the use of the new technology. The degree of difficulty in learning English and the complications of learning a foreign language such as English can gradually change by the frequent use of the new technology if students eventually add podcasting to their daily studying routines. Last but not least, the majority of students expressed the view that podcasts' content was interesting and helpful and, as a result, it is concluded that podcasts can be easily incorporated in the curriculum and once their content is appropriate, they can enhance student performance.

The current study attempted to add to the literature by exploring the efficiency of podcasting as part of the learning process in the Greek educational system. Despite the limited research on the nature and use of educational podcasts and based on the findings of this study, the following suggestions could be made. 


\subsection{Suggestions for Further Research}

10.2.1 Integrating Podcasting into the Curriculum of Secondary Education

Podcasting can be an effective tool for teaching foreign languages, allowing teachers to extend their lesson outside of the classroom and students to access class material at any time and any place they want (Shahramiri \& Gorjian, 2013; Nguyen, 2013; Wrigglesworth \& Harvor, 2017).

10.2.2 Podcasting as an Essential Component of Learning Foreign Languages: Receptive and Productive Skills

1) Classroom based podcast activities.

2) Student-found Podcasts

3) Benefits from authentic podcasts activities

Visual types can read and write podcast scripts, auditory types can recite and listen to the script, and kinesthetic types can create an activity from scratch and enjoy the satisfaction of this produce (Wrigglesworth \& Harvor, 2017; Chakowa, 2018). By looking for the appropriate podcasts for each class, students develop the skill to find material that is suitable for them and they also become independent learners. This may bring further benefits, such as incidental vocabulary acquisition through listening to podcasts (Rosell-Aguilar, 2013, 2017).

In light of the research limitations previously mentioned, suggestions for further research are proposed, which could focus on the following. Future studies could examine the effectiveness of podcasting in public schools, in a larger sample of students and in other subjects of lower or higher levels. Future studies can use a combination of quantitative and qualitative data and to conduct personal interviews with students as well as with educators and school counselors. Concluding, it could be argued that podcasting is a promising technological tool. The next stage is to set up a more exhaustive program of teaching interventions, which will last longer and will include teaching in more school subjects. The implementation of such a program in a larger group of students and the comparative study of data is expected to gain a better insight into the effectiveness of podcasting.

\section{References}

Abdous, M., Facer, B. R., \& Yen, C. (2012). Academic effectiveness of podcasting: A comparative study of integrated versus supplemental use of podcasting in second language classes. Computers \& Education, 58, 43-52. https://doi.org/10.1016/j.compedu.2011.08.021

Abt, G., \& Barry, T. (2007). The quantitative effect of students using podcasts in a first year undergraduate exercise physiology module. Bioscience Education, 10(1), 1-9. https://doi.org/10.3108/beej.10.8

Artyushina, G., Sheypak, O., Khovrin, A., \& Spektor, V. (2011). How to Improve Listening Skills for Technical Students. 14th International Conference on Interactive Collaborative Learning, Slovakia. https://doi.org/10.1109/ICL.2011.6059543

Ashraf, H., Noroozi, S., \& Salami, M. (2011). E-listening: The Promotion of EFL Listening Skill via Educational Podcasts. Proceedings of the 6th International Conference on e Learning (ICEL) (pp. 10-17). Oxfordshire, UK: Academic Conferences and Publishing International Limited.

Ashton-Hay, S., \& Brookes, D. (2011). Here's a story: Using student podcasts to raise awareness of language learning strategies. EA Journal, 26(2), 15-27.

Bin, Z., Xinxin, Y., \& Hui, L. (2017). Students' Perspectives on Using Online Sources and Apps for EFL Learning in the Mobile-Assisted Language Learning Context. Handbook of Research on Integrating Technology into Contemporary Language Learning and Teaching.

Bolliger, D. U., Supanakorn, S., \& Boggs, C. (2010). Impact of podcasting on student motivation in the online $\begin{array}{lllll}\text { learning environment. Computers and } & \text { 714-722. }\end{array}$ https://doi.org/10.1016/j.compedu.2010.03.004

Borgia, L. (2010). Enhanced Vocabulary Podcasts Implementation In Fifth Grade Classrooms. Reading Improvement, 46(4), 263-272.

Bybee, R. (2006). The BSCS 5E Instructional Model: Origins, Effectiveness and Applications

Cebeci, Z., \& Tekdal, M. (2010).Using podcasts as audio learning objects. Interdisciplinary Journal of Knowledge and Learning Objects, 2, 7-57. Publisher: Informing Science Institute. Retrieved from https://www.learntechlib.org/p/44813/

Chakowa, J. (2018). Enhancing Beginners' Second Language Learning through an Informal Online Environment. Journal of Educators Online, 15(1). 
Cohen, K., Manion, L., \& Morrison, L. (2008). Methodology of Educational Research. Athens: Metaihmio

Crigler, A. N., Just, M., \& Neuman, W. R. (1994). Interpreting visual versus audio messages in television news. Journal of Communication, 44(4), 132-149. https://doi.org/10.1111/j.1460-2466.1994.tb00703.x

Dendrinou, B., \& Karava, E. (2013). Foreign language education to promote multilingualism in Greece today. National and Kapodistrian University of Athens. Retrieved from http://rcel.enl.uoa.gr/files/rcel/texts/ODHGOS_TOMOS.pdf

Ducate, L., \& Lomicka, L. (2009). Podcasting: An effective tool for honing language students' pronunciation. Language Learning \& Technology, 13(3), 66-86.

Duncan, T. G., \& McKeachie, W. J. (2005). The making of the Motivated Strategy for Learning questionnaire. Educational Psychologist, 40, 117-128. https://doi.org/10.1207/s15326985ep4002_6

Edirisingha, P. (2007). The "double life" of an i-Pod: A case study of the educational potential of new technologies. Paper Presented at the Online Education Conference, Berlin: Germany.

Evans, C. (2008). The effectiveness of m-learning in the form of podcast revision lectures in higher education. Computers \& Education, 50, 491-498. https://doi.org/10.1016/j.compedu.2007.09.016

Fisher, L., \& Kim, D. (2013). Two approaches to the use of blogs in pre-service foreign language teachers' professional development. The Language Learning Journal, 41(2), 142-160. https://doi.org/10.1080/09571736.2013.790130

Hawke, P. (2010). Using internet- sourced podcasts in independent listening courses: Legal and pedagogical implications. Jalt CALL Journal, 6(3), 219-234.

Hinkelman, D. (2018). Assessments for Blended Language Learning. In: Blending Technologies in Second Language Classrooms. Palgrave Macmillan, London.

Istanto, W. I., \& Indrianti. (2011). Pelangi Bahasa Indonesia Podcast: What, Why and How? Electronic Journal of Foreign Language Teaching, 8(1), 371-384. Retrieved from http://eflt.nus.edu.sg

Jonassen, D. H., Carr, C., \& Yueh, H. P. (1998). Computers as mind tools for engaging learners in critical thinking. TechTrends, 43(2), 24-32. Retrieved from https://www.learntechlib.org/p/83372/

Kan, S. O. (2011). Critique of a Language-Learning Website. US-China Education Review, 8(5), 675-681.

Karathanasis I. (2012). Social Software Applications in Education and Distance Learning (Master's thesis, University of Patras Department of Mathematics-Computer Science in Education). Retrieved from http://nemertes.lis.upatras.gr/jspui/bitstream/10889/6067/1/\%CE\%B4\%CE\%B9\%CF\%80\%CE\%BB $\%$ CF\%

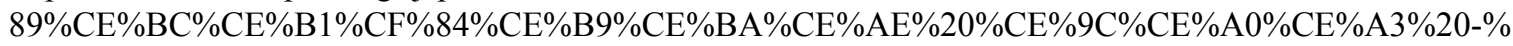
$20 \% \mathrm{CE} \% 9 \mathrm{~A} \% \mathrm{CE} \% 91 \% \mathrm{CE} \% \mathrm{~A} 1 \% \mathrm{CE} \% 91 \% \mathrm{CE} \% 98 \% \mathrm{CE} \% 91 \% \mathrm{CE} \% 9 \mathrm{D} \% \mathrm{CE} \% 91 \% \mathrm{CE} \% \mathrm{A3} \% \mathrm{CE} \% 97 \% \mathrm{C}$ E\%A3.pdf

Keller, J. M. (1987). Development and use of the ARCS Model of motivational design. Journal of Instructional Development, 10(3), 2-10. Retrieved from http://www.jstor.org/stable/30221294

Kennedy, M. J., Newman-Thomas, C., Aronin, S., Newton, J. R., \& Lloyd, J. W. (2014). Improving teacher candidate knowledge using content acquisition podcasts. Computers \& Education, 70, 116-127. https://doi.org/10.1016/j.compedu.2013.08.010

Kim, D. (2009). Innovative educational technology in your classroom in a global context. Essential Teacher, 6(1), $37-39$.

Kim, D. (2011). Incorporating podcasting and blogging into a core task for ESOL teacher candidates. Computers and Education, 56(3), 632-641. https://doi.org/10.1016/j.compedu.2010.10.005

Kokkini, K. (2010). The use of Podcasting in technology-supported teaching of mathematics (Master's thesis, University of Piraeus). Retrieved from http://dione.lib.unipi.gr/xmlui/bitstream/handle/unipi/4044/Kokkini. pdf? sequence $=2$

Kravari, A. (2011). The use of podcasting technology to teach the French language in primary school education (Master's thesis, University of Piraeus). Retrieved http://dione.lib.unipi.gr/xmlui/bitstream/handle/unipi/ 4063/Kravari.pdf? sequence $=2 \&$ isAllowed $=\mathrm{y}$

Lawlor, B., \& Donnelly, R. (2010). Using podcasts to support communication skills development: A case study for content format preferences among postgraduate research students. Computers \& Education, 54(4), 962-971. https://doi.org/10.1016/j.compedu.2009.09.031 
Lee, C. S., Tan, D. T. H., \& Goh, W. S. (2004). The next generation of e-learning: Strategies for media rich online teaching and engaged learning. International Journal of Distance Education Technologies, 2(4), 1-17. https://doi.org/10.4018/jdet.2004100101

Lee, M. J. W., \& Chan, A. (2007). Pervasive, lifestyle-integrated mobile learning for distance learners: An analysis and unexpected results from a podcasting study. Open Learning. The Journal of Open and Distance Learning, 22(3), 201-218. https://doi.org/10.1080/02680510701619810

Lum, L. (2006). The power of podcasting. Diverse Issues in Higher Education Web site

Ng'ambi, D. (2008). Podcasts for reflective learning. In G. Salmon, \& P. Edirisingha (Eds.), Podcasting for learning in universities (pp. 132-145). Berkshire, England: Open University Press.

Nguyen, D. (2011). Effectiveness of podcast lectures in English-writing courses for foreign-born learners at California Bay-area community colleges. ProQuest Dissertations and Theses, 175.

Panagopoulos, F. (2010). m-Learning: Learning with the use of mobile devices (Master's thesis Higher Educational Institution of Crete). Retrieved from http://nefeli.lib.teicrete.gr/browse/stef/epp/2009/ PanagopoulosFotis/attached-document-1288691305-567457-16990/Panagopoulos2009.pdf

Pintrich, P., \& Smith, D. A. F. (1991). A manual for the use of Motivated Strategies for Learning Questionnaire (MSLQ). University of Michigan.

Popova, A., \& Edirisingha, P. (2010). How can podcasts support engaging students in learning activities? Procedia-Social and Behavioral Sciences, 2(2), 5034-5038. https://doi.org/10.1016/j.sbspro.2010.03.816

Putman, S. M., \& Kingsley, T. (2012). The Atoms Family: Using Podcasts to Enhance the Development of Science Vocabulary. The Reading Teacher, 63(2), 100-108. https://doi.org/10.1598/RT.63.2.1

Reed, B. (2010). A brief history of smartphones. PCWorld. Retrieved from http://www.pcworld.com/article/ 199243/a_brief_history_of_smartphones.html

Rezapour, E., Gorjian, B., \& Pazhakh, A. R. (2012). The effect of Moodle and Podcast's instruction on vocabulary development among pre- intermediate EFL learners. AITM, 2(2), 32-40.

Rosell-Aguilar, F. (2017). State of the App: A Taxonomy and Framework for Evaluating Language Learning Mobile Applications, CALICO Journal, San Marcos, 34(2), 243-258. Sabet, M. K., \& Mahsefat, H. (2012). The impact of authentic listening materials on elementary EFL Learners' Listening Skills. International Journal of Applied Linguistics \& English Literature, 1(4), 216-229. https://doi.org/10.7575/ijalel.v.1n.4p.216

Rossell-Aguilar, F. (2007). Top of the pods-in search of a podcasting "podagogy" for language learning. Computer Assisted Language Learning, 20(5), 471-492. https://doi.org/10.1080/09588220701746047

Schmidt, T., \& Strasser, T. (2018). Media-Assisted Foreign Language Learning—Concepts and Functions. In C. Surkamp, \& B. Viebrock (Eds.), Teaching English as a Foreign Language. J. B. Metzler, Stuttgart. https://doi.org/10.1007/978-3-476-04480-8_12

Scutter, S., Stupans, I., Sawyer, T., \& King, S. (2010). How do students use podcasts to support learning? Australasian Journal of Educational Technology, 26(2), 180-191.

Shahramiri, P., \& Gorjian, B. (2013). The Effect of Podcast transcription Activities on Intermediate and Advanced EFL Learners' Writing Accuracy. Advances in Digital Multimedia (ADMM), 40(3), 194-199.

Shoretsanitou, P., \& Vekyri, I. (2010). Integration of ICT in education: prediction factors for educational use. Proceedings of the 2010 Conference for ICT in Education, University of Western Macedonia. httpp://dx.doi.org/10,12681/icodl.1086

Son, J. B. (2018). Language Skill-Based Approach. In: Teacher Development in Technology-Enhanced Language Teaching. Palgrave Macmillan, Cham. https://doi.org/10.1007/978-3-319-75711-7_6

Stanley, G. (2006). Podcasting: Audio on the Internet comes of age. TESL-EJ, 9(4). Retrieved from http://www-writing.berkeley.edu/TESL-EJ/ej36/int.html

Sweeny, R. T. (2005). Colloquy-Higher education for multitaskers. The Chronicle of Higher Education, 52(10). Retrieved from http://chronicle.com/colloquy/2005/10/millennial/

Tsimogiannis, A., \& Komis, B. (2010). ICT in Education: Exploring the Views of Secondary Education Teachers. Proceedings of the 2010 Conference for ICT in Education, University of Patras. Retrieved from http://nemertes.lis.upatras.gr/jspui/bitstream/10889/4566/1/nemetres_kalantzis_math.pdf 
Vavouraki, A. (2001). Introducing computers into education: A case study of the Greek situation (Doctoral thesis, Institute of Education, University of London).

Vavouraki, A. (2004). The introduction of computers into education as a state directed initiative: a case study of the Greek policies between the years 1985 and 2000. Educational Media International, 41(2), 145-156. https://doi.org/10.1080/09523980410001678601

Veronikas, W. W., \& Maushak, N. (2005). Effectiveness of Audio on Screen Captures in Software Application Instruction. Journal of Educational Multimedia and Hypermedia, 14(2), 199-205. Publisher: Association for the Advancement of Computing in Education (AACE), Waynesville, NC USA.

Vidal, K. (2010). Academic listening: A source of vocabulary acquisition? Applied Linguistics, 24(1), 56-89. Retrieved from https://sangu.ge/images/Linguistics_56.pdf

Wrigglesworth, J., \& Harvor, F. (2017). Making their own landscape: smartphones and student designed language learning environments. Computer Assisted Language Learning, 31(4), 437-458. https://doi.org/10.1080/09588221.2017.1412986

Yim, S., Saito-Stehberger D., \& Warschauer, M. (2017). The Long View, Teaching and Technology. https://doi.org/10.1002/9781118784235.eelt0455

Yoshida, R. (2013). Learners' self-concept and use of the target language in foreign language classrooms. System, 41, 935-951. https://doi.org/10.1016/j.system.2013.09.003

\section{Copyrights}

Copyright for this article is retained by the author(s), with first publication rights granted to the journal.

This is an open-access article distributed under the terms and conditions of the Creative Commons Attribution license (http://creativecommons.org/licenses/by/4.0/). 